\title{
岩石の打げき長孔穿孔に関する研究*
}

一長尺口ッドによる岩石の破碎機構について——

$\begin{array}{lllll}\text { 正会員 高 岡 } & \text { 三 郎** } \\ & & \text { 速 水 博 秀** }\end{array}$

\section{Studies on the Percussive Deep Hole Drilling of Rocks}

On the drilling mechanism of rock with the long rod -

\author{
Saburō TAKAOKA and Hirohide HAYAMIZU
}

In the percussive deep hole drilling test, the authors have studied on the drilling mechanism to increase the drilling efficiency and drilling speed with the long rod useing Inada Granite as a sample.

The results obtained are as follows:

(1) By measuring the stress distribution of drill rods, the chipping mechanism of rocks was observed clearly.

(2) The chipping resistance of rock termed chipping strength is constant, while the rock is chipping.

(3) The chipping strength was increased instantaneously at the initiatin of the chipping process of rock, as well as in the case of the mechanical properties of steel.

(4) The chipping strength changed proportionaly to the impact velocity of the hammer, but: has no relation with the hammer weight and the rod length.

(5) As the hammer weight increased, duration of chipping was prolonged.

(6) The chipping amount of rock were not influenced of the hammer weight, the impact velocity and the rod length, but has relation oniy to the impact energy of the hammer.

(7) On the deep hole drilling the elements which reduced the drilling efficiency do not due to increase of the rod length, but to the decreased output of the drilling machine caused by the friction between the rod and cuttings, the other hand it depend on the reduction of transverse rigidity of the rod.

\section{1. 緒言}

打げき式さく岩機による長孔穿孔に抢いて，その穿孔 能率の向上と穿孔可能限度の増大を計るためにはさく岩 機そのものの長孔穿孔性能抢よび穿孔孔中の破砕岩粉の 処理法等についての研究はもちろん必要であるが，ロッ ドの長大化に応してさく岩機セ゚ストンとロッドの相互作 用および岩石の破砕状況がぞのようになるか在究明する ことは先進ボーリングに代つて打げき式さく岩による長 孔穿孔の根本的有利性を確める上にまた長孔, 半長孔穿 孔による採掘法の改善を計るためにも重要な課題である。 しかるにこの点に関しては従来 2 球の㣫突理論より類推 した衝突勃率が考えられているのみであるが，この衝突 理論では実験の結果を説明するのに不充分であることが 確められている。

\footnotetext{
* 昭和30年12月24日受理，昭和 30 年10月京都に示ける地下資源関 係学協会合同秋季大会にて講演

** 工業技術院資源技術試験所第 6 部
}

また落鎚試験による岩石の打げきさく孔に関する研究 については東大下村教授も詳細な結果を報告されている。 ところでロッドが長大化した場合実際穿孔においていロ ッド重量の影響はもちろん存在するが，これ等に関古る 基碟的研究はあまり行われていない。そこでこのような 場合については弾性波理論の適応性が増大するものとし て，岩石の打げき破砕状沉の時間的経過を長尺ロッドを 介してこれに発生するヒズミ変化より究明することが出 来ると考えた。

そこで筆者等は研究の第 1 段階として実際の穿孔作業 に近い條件で長尺ロッドの穿孔機構を研究与る方法とし てロッド長さに応して試験岩石を任意の位置に固定し便 用ロッドもジョイントによるエネルギー損失等を考慮し て全部継目無 1本ロッドで先端に W. C. ビットをネジ 結合して，これに現用さく岩機々同程度の打けき力を与 える振子式横型打けき試験機によつて実験を行つた。す なわち単一並列打けきによつて岩石面に接触せしめたビ 
ットで岩石を破砝する際，岩石の示す抗力およびピスト ンとロッドの相互作用がロッドの長さにどのように関係 するかを特にロッドが長い場合について弾性力学的な解 一析およびロッド内に発生するとズミの測定によつて求め その際岩石破砕量がいかなる量により決定されるかを検 “討して穿孔速度とロッドの長さとの関係等を究明した結 果, 長尺ロッドによる穿孔機構の一端を明らかにするこ とが出来た。

\section{2. 弾性力学的解析}

さく岩用ロッド内部のヒズミ状況はセ゚ストンとロッド ，の相互作用拉よび岩石破砕の状況と密接な関倸があるか らロッド内部のヒズミ状況の測定によりピストンとロッ ドの相互作用抢よび岩石の破整状況を知ることが出来 る。従来 1 2m のロッドのヒズミについてはストレン ゲージを使用し搬送波回路あるいは C-R 増巾回路によ る測定が行われたが，㐫まりに弾性波速度が大きいため に，その破研現象を波状的に観測し，これを解析するこ とが不充分であつた。

またその理論的な関係は筆者等がさく岩機セ゚ストンと

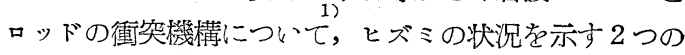
函数 $\partial u_{1} / \partial x, \partial u_{2} / \partial x$ の形をきめるには境界條件をきめる 必要があることを述べた。すなわちシャンク端の境界條 件は簡単に与元られるから岩石端の境界條件 $F_{(t)}$ をき めればピストンとロ、ッドの相互作用抢よび岩石破砕の状 況とロッド長さの関係が具体的に与えられるわけであ る。しかるに岩石端つ境界㣠件についてはこれをきめる ための理論的な研究はまだなく、それが本研究の一つの 目的でもあつたが，幸い今回の実験によりロッドが比較 “的長く第 1 大射波の有与る全エネルギが衝突前ピストン の有していた運動エネルギとほとんど等しいと考えられ る場合については，ビットが岩石を破砕して岩石に貫大 しつつある時期に岩石が示す抗力, すなわち抗砕力* は 大体一定であることが明らかになつた。すなわちその大 きさ $F$ は近似的に

$$
F=k v \text {. }
$$

ただし $v:$ そ゚ストンの打けきき速度

となり，打げき速度 $v$ のに関係し，かつビットの貫大 停止後はゼットが岩石から分離するまで岩石端は固定端 とほとんど同様の境界條件を有することがわかつた。

よつてこれにともないロッド雨端の境界條件は理論的 に次のように与えられることになる。

* 打住驾孔において, 岩石の破碎に抗する機械的性質で, 鋼の 降伏点に類似しておりこれれを岩石の抗碎力こ名ブけてみれ。

** 以下各式の記号は参考交献 1)において用いれ記号ミ同一の量 走す

“淮** $F=0$ ならは第 1 反射波後牛も引張ヒズミ波こなり，ピストン ミロッドは再び接触するここなくピストンは反発されない。こ のこミは参考交献 1)に示した。
すなわちシャンク端において $0<t<\frac{2 l}{a}$ の間はロッドはセ゚ストンにより打げきされる から**

$$
\frac{W}{g}\left(\frac{\partial^{2} u t}{\partial t^{2}}\right)_{x=l}=-E A\left(\frac{\partial u}{\partial x}\right)_{x=l}
$$

で与えられる。ただし上記は $F<E A \frac{v}{a}$ なる場合であ つて, $F>E A \frac{v}{a}$ ならばセ゚ストンとロッドの接触時間 は少し伸び（2）式が成立する時間は幾分長くなるが， 実験の結果 $F<E A-\frac{v}{a}$ であるから (2) 式は $0<t<l / 2 a$ の閒のみ成立することになる。

$\frac{2 l}{a}<t<\frac{2 l}{a}+t_{2}$ の聞は $F^{r}<E A \frac{v}{a}$ なる結果第1 反 射波前半が䥽七ズミ波となり，t=2l/aにピストンと ロッドは分離しロッドシャンク端は自由端になるので

$$
\left(\frac{\partial w}{\partial x}\right)_{x=\imath}=0
$$

で与えられる。しかるに岩石の抗砕力 $F$ が時間に対して 不変なること抢よび岩石の破砕停止後岩石端が固定端に なることから第 1 反射波後半は圧縮ヒズミ波となるので ピストンとロッドは再び接触する。すなわち $t_{2}$ は第 3 四 に示すようにシャンク端が自由端として存在する時間を 示高。

$\frac{2 l}{a}+t_{2}<t<\frac{2 l}{a}+t_{3}$ の間はて゚ストンとロッドが接 触しているので再び ${ }^{a}(2)$ 式と同じ境界條件になり $\frac{2 l}{a}$ $+t_{2} \sim \frac{2 l}{a}+t_{3}$ なる時間中にピストンに作用する才積に よりピストンは反発される。****次に

$\frac{2 l}{a}+t_{3}<t$ においていロッドシャンク端はピストン を反発分離した結果，なんの拘束もなくなるから自由端 となり（3）式と同じ境界條件になる。

一方岩石端は $t<\frac{l}{a}$ に拈いて $(\partial u / \partial x)_{x=0}=(\partial u / \partial t)_{x=0}$ $=\left(u^{i}\right)_{x=0}=0$ であり

$\frac{l}{a}<t<\frac{l}{a}+t_{1}$ の間は第 1 大射波により岩石を破 砕するから

$$
-k v=E A\left(\frac{\partial u}{\partial x}\right)_{x=0}
$$

で与えられる。すなわち $t_{1}$ は第 3 図に示すように岩石の 破砕継続時間を示す。

$\frac{l}{a}+t_{1}<t<\frac{3 l}{a}$ の間はどットは破势貫入を停止し 岩石面に静止するから

$$
\left(\frac{\partial u}{\partial t}\right)_{x=0}=0
$$

で与えられる。さらに $t>\frac{3 l}{a}$ についても各時刻に対す る境界條件が与えられるが後に説眀する理由により $t=$ $\frac{3 l}{a}$ 以後のロッドと岩石の相互作用はほとんどなくなる から近似的に

$$
\left(\frac{\partial u}{\partial x}\right)_{x=0}=0
$$

で与えることが出来る。

以上の境界條件を満足する解を求めれば 
第1大射七ズミ波 $\left(\frac{l-x}{a}<t<\frac{3 ?-x}{a}\right)$

$$
\frac{\partial u_{1}}{\partial x}=-\frac{v}{a} \exp \left\{-\frac{P A}{m a}\left(t-\frac{l-x}{a}\right)\right\}
$$

第1反射七各ミ莨 $\left(\frac{l+x}{a}<t<\frac{l+x}{a}\right.$

$$
\begin{aligned}
& \frac{\partial u_{2}}{\partial x}=\frac{v}{a} \exp \left\{-\frac{\left.+t_{1}\right)}{m a}\left(t-\frac{l+x}{a}\right)\right\} \\
& -\frac{k v}{E A}
\end{aligned}
$$

ただし $t_{1}=\frac{m a}{E A} \log _{e} \frac{2 E A}{k a}$

第1反射七バミ波 $\left(\frac{l+x}{a}+t_{1}<t<\right.$

$\left.\frac{3 l+x}{a}\right)$

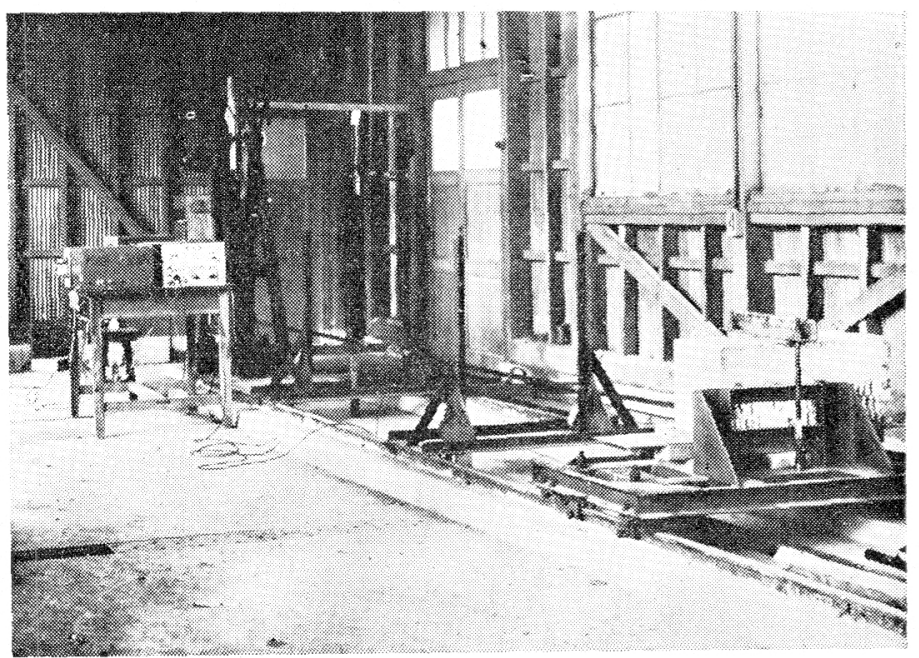

$\frac{\partial u_{2}}{\partial x}=-\frac{v}{a} \exp \left\{-\frac{E A}{m a}\left(l-\frac{l+x}{a}\right)\right\}$

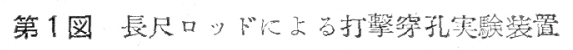

第 2 大射七ズミ波 $\left(\frac{3 l-x}{a}<t<\frac{3 l-x}{a}+t_{1}\right)$

$\frac{\partial u_{1}}{\partial x}=-\left[\frac{v}{a} \exp \left\{-\frac{E A}{m a}\left(t-\frac{3 l-x}{a}\right)\right\}-\frac{k v}{E A}\right](11)$

第2 入射七ズミ波 $\left(\frac{3 l-x}{a}+t_{1}<t<\frac{3 l-x}{a}+t_{2}\right)$

$\frac{\partial u_{1}}{\partial x}=\frac{v}{a} \exp \left\{-\frac{E A}{m a}\left(t-\frac{3 l-x}{a}\right)\right\}$

ただし $t_{2}=\frac{m a}{E A} \log _{e}\left\{\frac{k a}{E A}\left(1+\log _{e} \frac{2 E A}{l_{a} a}\right)-1\right\}^{-1}$.

第 2 入射七バミ波 $\left(\frac{3 l-x}{a}+t_{2}<t<\frac{3 b-x}{a}+t_{3}\right)$

$\frac{\partial u_{1}}{\partial x}=\frac{v}{a} \exp \left\{-\frac{E A}{m a}\left(1-\frac{3 l-x}{a}\right)\right\} \times\left\{2 \frac{E A}{m a}\left(t-\frac{3 l-x}{a}\right.\right.$

$$
\left.\left.-t_{2}\right)-1\right\}
$$

たたし $t^{3}=\frac{m a}{E A}+t_{2}$

第 2 大射波 $\left(\frac{3 l-x}{a}+t_{3}<t<\frac{5 l-x}{a}\right)$

$$
\frac{\partial u_{1}}{\partial x}=\frac{v}{a} \exp \left\{-\frac{E A}{m a}\left(t-\frac{3 l-x}{a}\right)\right\}
$$

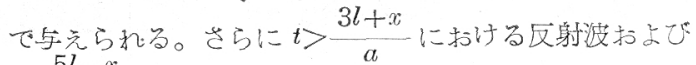

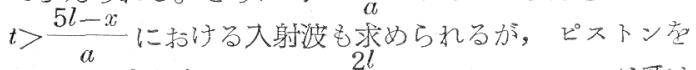

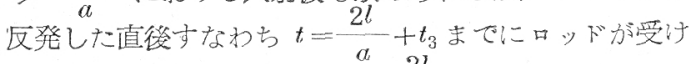

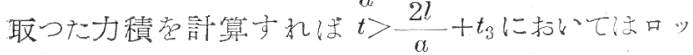
下゙は岩石と反対方向に運動量存有することがわかるので

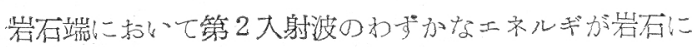
供給されるが，近似的には岩石端は自由端と考光ること が出来 (6) 式老与元たわけである。すなわち以後は口 ッドが自由運動危行うと溚えられるので大体におおて大 射ヒズミ波，反射ヒズミ波の波形㩐しく符号が反対に なるのみと考劣られる。

* 詳紼については参考交献 1 在参照のこ气

以上のヒズミ波に詨芯して次の関偾が導かれる。

a) 岩石に吸收导乱るェネルギHは

$$
\begin{aligned}
H & =\int_{l / a}^{\frac{l}{a}+t_{1}} a E A\left[\left\{\frac{v}{a} \exp \left(-\frac{E A}{m a}\left(t-\frac{l}{a}\right)\right)\right\}^{2}\right. \\
& -\left\{\frac{v}{a} \exp \left(-\frac{E A}{m a}\left(t-\frac{l}{a}\right)-\frac{l v}{E A}\right\}^{2}\right] d t
\end{aligned}
$$

$H=\frac{1}{2} m v^{2}\left\{4 \frac{k \alpha}{E A}-2\left(\frac{k a}{E A}\right)^{2}\left(1+\log _{e} \frac{2 E A}{k a}\right)\right\} \cdots$

b）ビットの岩石への貫入速度Vは

$V=-2 v \exp \left\{-\frac{E A}{m a}\left(t-\frac{l}{a}\right)\right\}+\frac{k a}{E A} v$

$\frac{l}{a}<t<\frac{l}{a}+t_{1}$

c）貫入深度 $D$ は

$D=m v\left\{k\left(\frac{a}{E A}\right)^{2}\left(1+\log _{e} \frac{2 E A}{k a}\right)-2 \frac{a}{E A}\right\} \cdots$

d）ピストンの反発速度 $v^{\prime}$ は

$v^{\prime}=2 v\left\{\frac{k a}{E A}\left(1-\log \frac{k a}{2 E A}\right)-1\right\} e^{-1}$

e）ピストン民発後のロッド運動量 $T^{\prime \prime}$ は

$T^{\prime}=m v\left[\frac{k a}{E A} \log _{e} \frac{2 E A}{k \omega}\left(1+2 e^{-1}\right)\right.$

$$
\left.+\left(\frac{k c \cdot}{E A}-1\right)\left(1-2 e^{-1}\right)-\exp \left\{-\frac{2 E A l}{m a^{2}}\right\}\right]
$$

で与えられる。

以上理論的に求められた結果在列举したが, 本理論に おるてでッド内部粘性区じ外部よりの摩擦抵抗, さら にロッド細部の形状，ヂョイントの影響等を無視してい るので，理諭がぞの程度穿孔時の岩石の破鿙現象に近似 しているか觉確めるために过の実験を行らた。

\section{3. 实験裝置および方法}

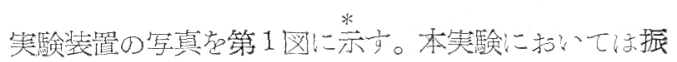


于の打げきに際してビット艺岩石面に接触さしめた状態 て岩不起破础し，かつ実験條件支同一にするため岩石つ

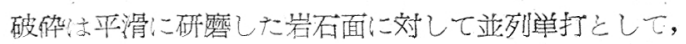
各打げきによる岩石破斩部が互いに影響しないように破 筑箇所は充分に間隔を取り，各條件の岩石破砕量は10回 の打: 导破砕実験の平均值老取つた。

またロッドヒズミの測定は岩石破伜実験の際にロッド 中央部に抢いてストレンゲージにより前報と同じ万法で 同一の測定器によつて行つた。なお口ッドとズミの測定 は打げき端㧍よび衝突端附近に括いても 行つだが、ロッドの応才分布測定を目的 としたものではないので, 両端の現象の 時間的経過死もつとも容易にかつ明確に 測定出来る䇠所として中央部在選定し た。

次に実験に使用したロッド，ビットお よび武験岩石等の要因を示す。

\section{$3 \cdot 1$ ロッドおよびビット}

岩石の打げき破砕実験に使用したロッ

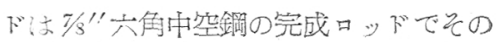
長さは1，2，4，6，8，10mの6 種とし とズミ測定は長さ $3,6,10 \mathrm{~m} の 3$ 種の ものにつタての年行つた。使用したビッ 下沈がージ $38 \mathrm{~mm}$ ，一文字型及先解度

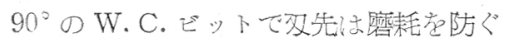
ため切 $0.2 \mathrm{~mm}$ の面取劣行つている。

\section{2 試験岩石及び岩石固定台}

試駼岩石莰茨城県西茨城郡稻出産出の 黒玨母質花菵岩でるの主な造岩鉱物は黑 雲母, 斜長石, 石英て $\mathrm{SiO}_{2}$ 含有量 78.8 \%, ショア一硬度 90〜95のもので, 大 きさは1尺×1尺×2尺とし表面は荒砥で 充分平滑に研磨して仕上げ表面状況虎一 様にした。なお岩石固定台はロッド長さ に笞じてレール上を移動也しめ，適当の 位置にクランプにより固定する。

\section{4. 実験結果および考察}

$4 \cdot 1$ ヒズミ測定
前記の実駼装置により岩石破䂥の際，ロッド中央部に 生す゚るレズミのブラウン管カジがラフによる記録例在 示すと第2四のようであり，オシログラフと理諭による ヒズミ状況在比較したのが第3図でる。すなうち同図 よりわかるように理諭と実際現象との近似度はかなり良 好であるが細かい点については幾分の差異があるのでこ の差の程度走示す 1 例として第 1 大射波の最大波高值支 び波高半減時間侾比較すれは第1表のようになる。すな わち同表よりわかるように第1 大射波の最大波高值は理

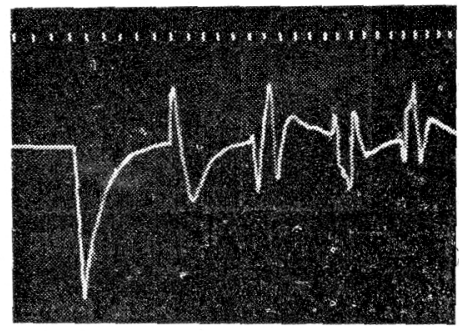

$5.08 \mathrm{~kg} \times 5.12 \mathrm{~m} / \mathrm{sec}$

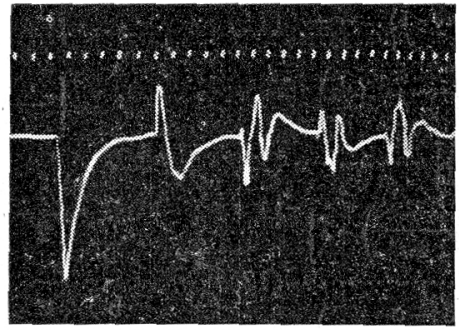

$4.31 \mathrm{~kg} \times 5.15 \mathrm{~m} / \mathrm{sec}$

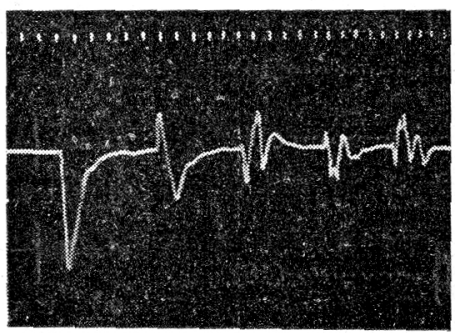

$3.31 \mathrm{~kg} \times 5.22 \mathrm{~m} / \mathrm{sec}$

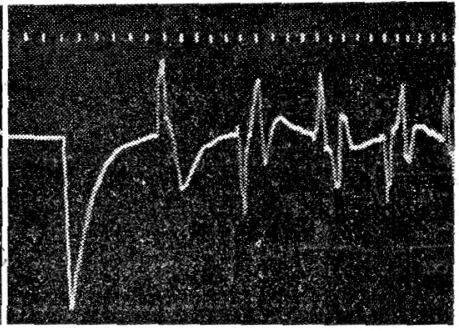

$5.08 \mathrm{~kg} \times 6.26 \mathrm{~m} / \mathrm{sec}$

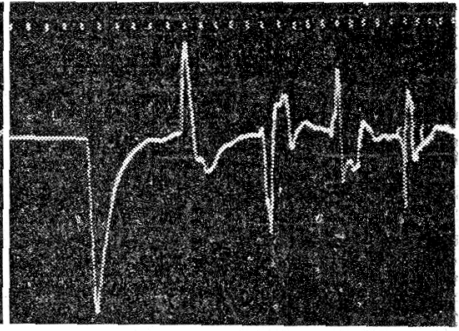

$4.31 \mathrm{~kg} \times 6.30 \mathrm{~m} / \mathrm{sec}$

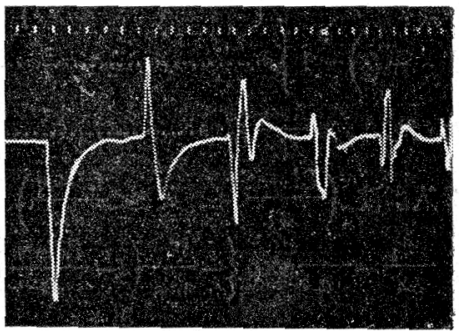

$3.31 \mathrm{~kg} \times 6.38 \mathrm{~m} / \mathrm{sec}$

註特点は1目 $2 / 10,000 \mathrm{sec}$ 宫真下の数字は打整体重量 $\times$ 打㢣速度

第2図 $6 \mathrm{~m}$ ロッドの中央部に打けるヒズミ状況

第 1 表 第 1 大射波波高值扣よび牛減時間

\begin{tabular}{|c|c|c|c|c|c|c|c|c|c|}
\hline \multirow{2}{*}{$\begin{array}{c}\text { 打使当体重量 } \\
(\mathrm{kg})\end{array}$} & \multirow{2}{*}{$\begin{array}{l}\text { 打优速度 } \\
(\mathrm{m} / \mathrm{sec})\end{array}$} & \multicolumn{2}{|l|}{ 琻論 } & \multicolumn{2}{|c|}{$3 \mathrm{~m}$ ロッドにおける測定值 } & \multicolumn{2}{|c|}{$6 \mathrm{~m}$ ロッドにおける測定做 } & \multicolumn{2}{|c|}{ 10m ロッドにおける測定值 } \\
\hline & & $\begin{array}{l}\text { 波 高 值 } \\
\left(\mathrm{kg} / \mathrm{cm}^{2}\right)\end{array}$ & $\begin{array}{l}\text { 波高牛減 } \\
\text { 時䦬 }(t)\end{array}$ & $\begin{array}{l}\text { 波 高 值 } \\
\left(\mathrm{kg} / \mathrm{cm}^{2}\right)\end{array}$ & $\begin{array}{l}\text { 波亮牛減 } \\
\text { 封䦭 }(t)\end{array}$ & $\begin{array}{l}\text { 波 高 值 } \\
\left(\mathrm{kg} / \mathrm{cm}^{2}\right)\end{array}$ & $\begin{array}{l}\text { 波高生減 } \\
\text { 時閴 }(t)\end{array}$ & $\begin{array}{l}\text { 波 高 值 } \\
\left(\mathrm{kg} / \mathrm{cm}^{2}\right)\end{array}$ & $\begin{array}{l}\text { 波高牛減 } \\
\text { 時間 }(t)\end{array}$ \\
\hline $\begin{array}{l}3.31 \\
4.31 \\
5.08 \\
3.31 \\
4.31 \\
5.03 \\
3.31 \\
4.31 \\
5.08\end{array}$ & $\begin{array}{l}3.69 \\
3.64 \\
3.62 \\
5.22 \\
5.15 \\
5.12 \\
6.38 \\
6.30 \\
6.26\end{array}$ & $\begin{array}{l}1,190 \\
1,470 \\
1,460 \\
2,100 \\
2,080 \\
2,060 \\
2,580 \\
2,540 \\
2,530\end{array}$ & $\begin{array}{l}1.46 \times 10^{-1} \\
1.90 \times 10^{-4} \\
2.24 \\
1.46 \\
1.90 \\
2.24 \\
1.46 \\
1.90 \\
2.24\end{array}$ & $\begin{array}{r}970 \\
1,130 \\
1,170 \\
1,470 \\
1, € 30 \\
1,700 \\
1,930 \\
2,090 \\
2,010\end{array}$ & $\begin{array}{l}1.2 \times 10.4 \\
1.7 \\
2.0 \\
1.2 \\
1.6 \\
1.8 \\
1.2 \\
1.3 \\
2.0\end{array}$ & $\begin{array}{r}980 \\
1,090 \\
1,090 \\
1,360 \\
1,630 \\
1,740 \\
1,850 \\
1,930 \\
1,930\end{array}$ & $\begin{array}{l}1.3 \times 10^{-4} \\
1.8 \\
1.9 \\
1.2 \\
1.8 \\
1.8 \\
1.2 \\
1.7 \\
2.0\end{array}$ & $\begin{array}{l}1,050 \\
1,050 \\
1,170 \\
1,480 \\
1,700 \\
1,740 \\
1,740 \\
2,010 \\
2,160\end{array}$ & $\begin{array}{l}1.2 \times 10^{-4} \\
1.8 \\
2.0 \\
1.0 \\
1.6 \\
1.7 \\
1.1 \\
2.0 \\
1.8\end{array}$ \\
\hline
\end{tabular}




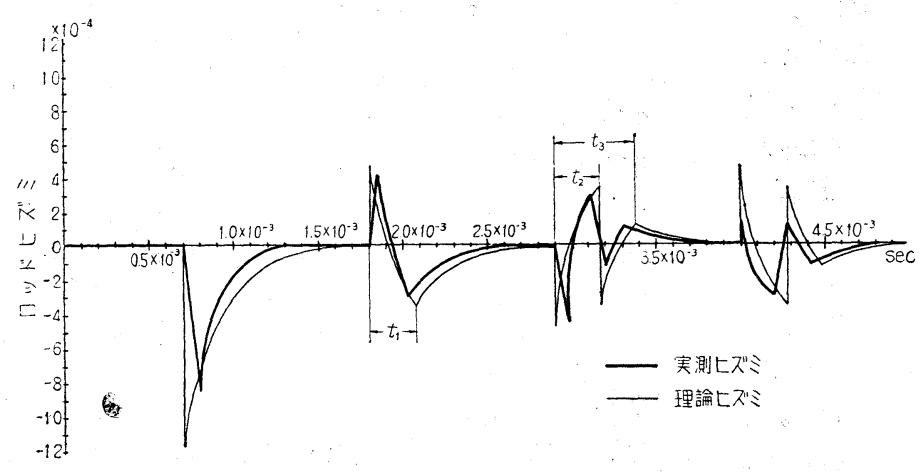

ロッド $6 \mathrm{~m}$, 衝突体重量 $3.31 \mathrm{~kg}$, 衙突速度 $6.38 \mathrm{~m} / \mathrm{sec}$

第3図、理論とズミと実測とズミの比較
様な結果は花崗岩についてしかも長尺 ロッドに生ずるとズミを測定する方法 により得られたものであり，破砕時に おける岩石面之直角軸方向の時間之応 カの関係が一忘明らかにされたわけで 亦るが，各種岩石の破砕現象はさらに 複雑な要素を持つものであろう。なお 岩石破砕中抗䂶力の時間に対守る不変 部をとつてその大きさ $F$ が何によりき まるかを検討することは興味ある問題 であるがここでは単に打げき速度と の関係を示すと第 5 四のようになる。

論值よりも測定值の方が低く，その傾向 は打げき体重量の小なる方が著しい。こ の理由は先にも述べたが打けきき体が弾性 変形することと，ロッド中に生じたヒズ ミ波の周波数の高い部分が波の進行とと もに急速に減衰することによるものと考 えられる。

次に理論半減時間とオシログラフより の測定による半減時間は大体近似してい るので，実際に生ずる波形は理論波形と 相似するが波形より求められる弹性波速 度は $5,100 \sim 5,500 \mathrm{~m} / \mathrm{sec}$ 程度てあって 測定の誤差を考慮すれば大体理論的に与 兄られる速度 $5,200 \mathrm{~m} / \mathrm{sec}$ 程度である。

\section{$4 \cdot 2$ 岩石の抗研力}

ビットによつて岩石を打げき破轨する

際岩石の示卞抗力,すなわち抗研力 $F$ は境界條件 (4) 式 を考慮すれば（7）式に相当するオシロがラフ上の第 1 入射波と (11) 式に相当するオシロがラフ上の第1反射 波との羑をとればよいがとの数例を示すと第 4 図のよう になる。すなわち抗砕力゙゙は多くの場合岩石の破砕進行 中ほとんど変らず，鋼材の引張試験における降伏々類似 の現象を示すが，鋼材の弓張試験においても降伏開始時 に上降伏点が存在することがあると同様に，岩石も破砕 開始僢間に拕砕力が上昇することもある。もちろんこの

第 2 表 岩石破碎継続時間

\begin{tabular}{|c|c|c|c|c|c|}
\hline $\begin{array}{l}\text { 打けき体 } \\
\text { 重量 kg }\end{array}$ & $\begin{array}{c}\text { 打ばき速度 } \\
\mathrm{m} / \mathrm{sec}\end{array}$ & $\begin{array}{l}\text { 理諭破壁 } \\
\text { 時間 } t_{1}\end{array}$ & $\begin{array}{l}3 \mathrm{~m} \square ッ ト ゙ \\
\text { における破 } \\
\text { 碎時間 } t_{1}\end{array}$ & 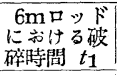 & $\begin{array}{l}10 \mathrm{~m} \square ッ ト F \\
\text { における破 } \\
\text { 碎時間 } t_{1}\end{array}$ \\
\hline 3 & & $2.62 \times 10^{-4}$ & $2.0 \times 10^{-4}$ & $2.0 \times 10^{-4}$ & $2.2 \times 10^{-4}$ \\
\hline & & 2.62 & $2.0 \mathrm{~J}$ & $2.0 \mathrm{~J}$ & 2.4 \\
\hline & 6.38 & 2. 62 & 2.0 & 2.0 & 2.2 \\
\hline & & 3.42 & 2.4 & 2.5 II & 2.2 \\
\hline & 5 & 3.42 & 2.4 & 3.0 & 2.5 \\
\hline & & 3.42 & 3.0 & 2.5 & 3.0 \\
\hline & & 4.03 & 3.0 & 3.0 & 3.5 \\
\hline & & 4.03 & 3.0 & 3.5 & 3.0 \\
\hline & & 4.03 & 3.2 & 3.2 & 3.5 \\
\hline
\end{tabular}

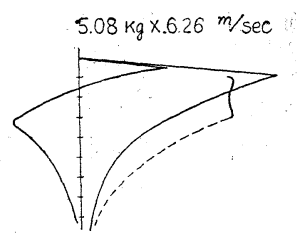

$5.08 \mathrm{~kg} \times 5.12 \mathrm{~m} / \mathrm{sec}$

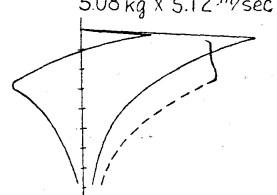

$5.08 \mathrm{~kg} \times \mathbf{x} .3 .62 \mathrm{~m} / \mathrm{sec}$

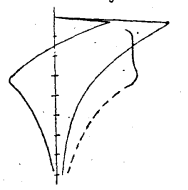

註 グラフ左側の数字は打げ体重量×打けき速度 時間軸 1 目盛 $1 / 10^{4} \mathrm{sec}$

$4.31 \mathrm{~kg} \times 5.15 \mathrm{~m} / \mathrm{sec}$

$4.31 \mathrm{~kg} \times 3.64 \mathrm{~m} / \mathrm{sec}$

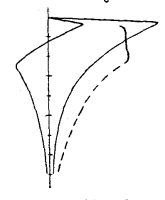

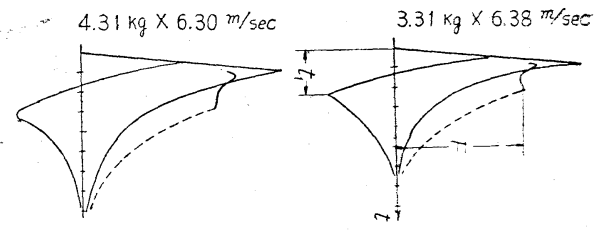
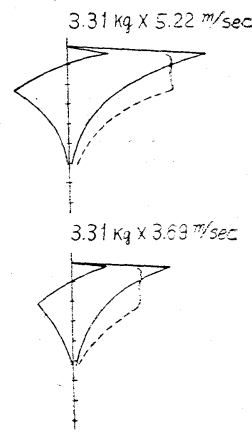

4 図 抗碎力, 破碎時間と打げき重量, 打げき速度との関侕

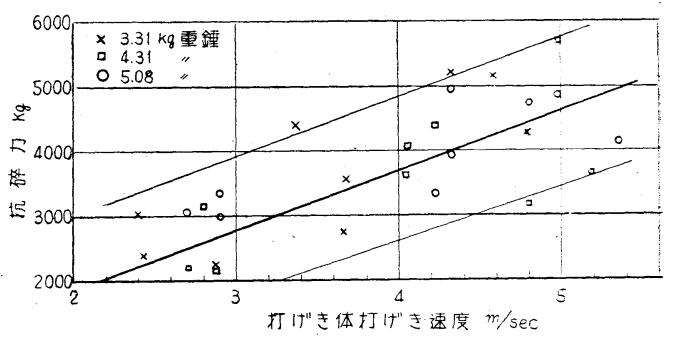

第 5 図 抗碎力と打げき体打げき速度との関保

図中抗研力は打げき速度 $v$ と一次的な関係があつて，打 げき体重量Wにはあまり関係がない。すなわち岩石の破 砕持続時間 $t_{1}$ は打けき体重量 $W$ により变化するが，抗 确力は打げき体重量およびロッド長さには無関係と考元 られるので第1近似として第 (1) 式に示した関係が得 られる。このことより抗砕力はゼッ下の岩石への貫大初 速のみに比例すると云う関倸が得られるがひしろこの方 が本質的な関係と考えられる。 
なおをは単位打げき速度に対して岩石が示す抗研力で あるが，これは岩石の種類，ビットの形，破砕部の状況 およびロッドの大きさ等による定数と考えられる。次に 岩石の破据継続時間を第 2 表に示すが実測時間が理論時 間より短かいのは第 1 入射波の実際の大きさが理論値よ りも小さいことによると思われる。

\section{$4 \cdot 3$ 岩石の破研状況}

岩石の破砕状況は理論的には (17)(18)(19) 式により 示されるが (17) 式によれば岩石に吸収されるエネルギ は打けき体が有する運動ェネルギのみに比例している。 同様に第6 図に示すように岩石破䂶量は岩石に吸収され たェネルギのみに関係することが知られる。なお第7図 において同一打げきェルギに対してロッド長さの増大 と共に岩石破砕量が減少しているのは，ロッドの内部粘 性掞よびロッド支持に使用したコロ軸受による摩擦抵抗 がロッド長さの増大とともに大きくなり，弾性波ェネル ギの一部が熱ェネルギに変換されるのて理論的に求めら れる吸収ェネルギより小さくなるためと，ロッド長さの 増大による横剛性の減少によるものではないかと考元ら れる。

まだッドが短かい場合は本理論の適用範囲から外れ るので岩石の破矿機構が幾分暴なり第 2 入射波によつて

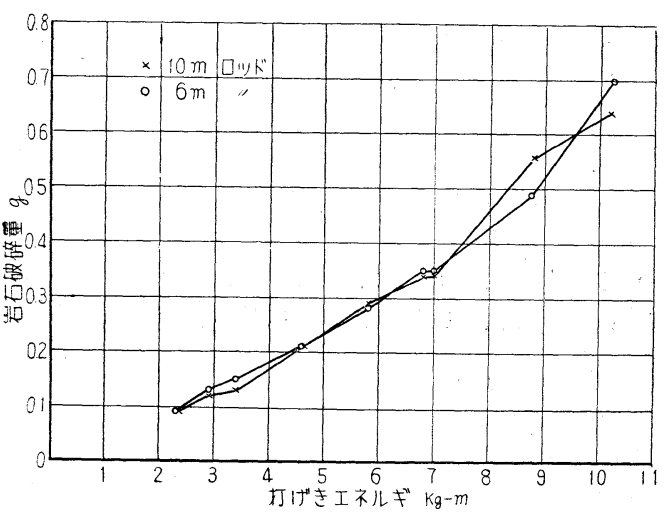

第6図 打げきエネルギーと岩石破碎量との関係

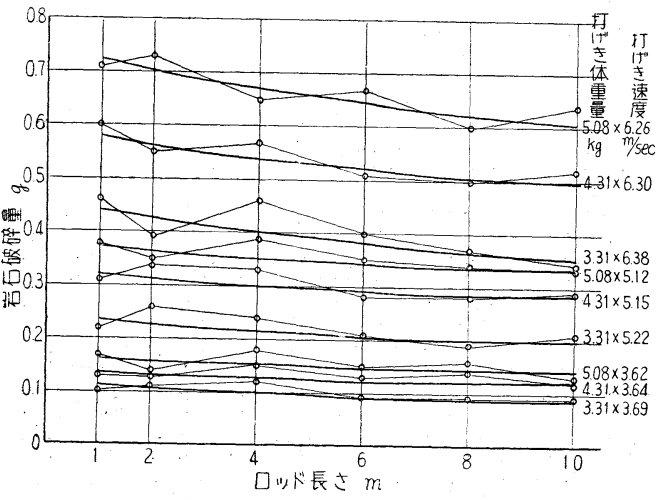

第7図ロッド長さと岩石破碎量との関保
第 3 表 打げき体反発速度

\begin{tabular}{|c|c|c|c|c|c|}
\hline $\begin{array}{l}\text { 打代剙体 } \\
\text { 重量 } \mathrm{kg}\end{array}$ & $\mid \begin{array}{c}\text { 打げき速度 } \\
\mathrm{m} / \mathrm{sec}\end{array}$ & $\begin{array}{l}\text { 理論反発速 } \\
\text { 度 } \mathrm{m} / \mathrm{sec}\end{array}$ & 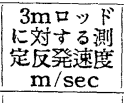 & $\begin{array}{c}6 \mathrm{~m} \text { 口 } \\
\text { 対する測 } \\
\text { 定反発速度 } \\
\mathrm{m} / \mathrm{sec}\end{array}$ & 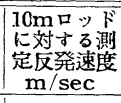 \\
\hline $\begin{array}{l}3.31 \\
3.31 \\
3.31 \\
4.31 \\
4.31 \\
4.31 \\
5.08 \\
5.08 \\
5.08\end{array}$ & 6 & 1. & $\begin{array}{l}0.94 \\
0.94\end{array}$ & & $\begin{array}{l}0.86 \\
1.10 \\
1.22 \\
0.69 \\
0.84 \\
1.14 \\
0.62 \\
0.82 \\
1.25\end{array}$ \\
\hline
\end{tabular}

も続いて岩石が破砕されるため之考えられるので，この 点に関してはさらに研究を行いたい。

なお，ビットの貫入速度及び貫入深さは理論的に第 (18)(19) 式で与えられるが今回は実測しなかつだ。

\section{$4 \cdot 4$ 打げき体反発速度}

打げき体の反発速度は理論的に(20) 式で与元られる。 すなわち反発速度は岩石の抗砕力に関係するがロッド長 さ，打けきき体重量には関倸なく打げき体の打げき速度の みに関係がある。

これを岩石の破确時に測定した打行き体反発速度と比 較してみると第 3 表のようで害測值は幾分のバラッ市は あるが全体として理論値とよく一致しており理論による 推定が正しいことを示している。

\section{5. 結一論}

以上長尺ロッドを介して単打試験により岩石の打げき 破研に関する理論的および実験的研究を行つた結果判明 した事項を要約すれば次のようになる。もちろん本研究 結果は花崗岩についての場合で，岩石の相違による影響 についてはさらに実験を進める必要があると同時にフ、1 一ドクリアランスが，存在する場合についても検討を要 するであろうが，実際の長孔呀孔に括いては穿孔能率が 低下寸るのに対して本実験條件による単打試験ではロッ ドの長大化のみによる岩石破砕量に対しての影響は活之 んど認められないものと考元る。なお岩石の破确状況は ロッドを介して推定されたものであつて，実祭にはさら に複雑な現象を呈するであろう。

1）長尺ロッドを使用することによつて，ビットによ る岩石の破硪機構抢よびロッドとピストンの相互作用等 をそのヒズミ状況より明膫に観察することが出来た。

2) 以上に示した理論は $A l \gamma / W>2$ すなわち打げき 体重量の約 2 倍以上の重量のさく岩機用ロッドによる岩 石の打げき破硴に対しては相当正榷に適用される。

3 ) ロッドを介してどットにより岩石の打げき破砝を 行う場合，ロッドに発生するとズミ波を測定する方法に よれば岩石の破砕が進行中，岩石の示す抗力はほほ一定 の値をとることが推定される。これは鋼材等の引張試験 に抢汀る降伏現象に類似するものと考元られるので抗研 
カとでも称されるものではなからうか。

4）鋼材に上降伏点が存在与るように岩不について その打げき破砕開始時に抗砕力の局部上昇炎生ずること がある。

5) 抗花力は打げき体の衝突速度に比例して変化する が，打げき体重量，口ッド長さ等にほとんど関倸かなく 打げき体重量の增加により破砕継続時間が長くなるだけ である。

6）上記のロッドヒスミミの測定により求められる抁砕 才は岩石のさく岩抵抗在示す一つの要素と考无られる。

7) 岩石破砕量心岩石に吸收されたェネルギの孙関 係する。

すなはち長尺口ッドによる岩不穿孔にニ拈いて等孔能率 觉低下させるものはロッドの長さあるいは重量に直接原 因古るものではなく，染孔孔内にこ打けっロッドの回転抵 抗によるさく岩機自体の出力の低下とロッドと繰粉或、 は孔壁の摩擦による伝墦エネルギの減衰, ロッドギョイ ントに抢けるェネルギ反射抢よび横剛性の低下等であろ う。そこでこれ等の諸点虎改良することにより打げき長 孔呀孔の能率の向上と可能穿孔長の増大が期待され，そ

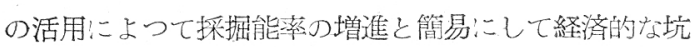

内探鉣等:二一筧役立つものと考える。

謝辞：本研究を実施与尚にあたつては，前所長黒川真 武氏，前部長三輸忠利氏および現部長敛木俊夫氏より理 解ある御援助奌頂いた。また試験用各種長尺ロッドにつ いては三菱鋼材株式会社社長伊藤宽治氏及び同社研究課 長内山道良氏に二特別の御配慮忞頂いた。な抢当所の佐々 木和郎氏より測定器支抢借りした他, 田代鉄人, 三沢茂 夫の両君は終始熱心に実験に協力された。これ等の御好 意に対しここに深く感謝の意定表する次第である。

\section{参若 文 献}

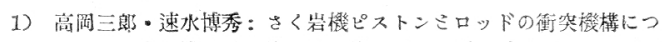
W七, 日本鉱業会誌, 第72䉥, 813 号。炤和 31 年 3 月, $9 \sim 12$ 頁

2)下村布太郎：岩石の打整さ〈孔に関する研究，日本鉱業会誌，第 71 怣, 第803号, 昭和 30 年 5 月, $1 \sim 7$ 面

3) 清水浩・高田勝：さく岩機用錐の応力について, 九州大学工学部

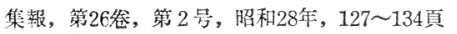

4) B. F. Shepherd: The connecting link in percussion drilling. The problem'what-why-how ?, Mining Congress J. Nov. 1954, pp. 28 31

5) Engel, L. u. M. H. Gloeckner: Dynamik des Abbauhammers, Glückauf, 45/46, 1951

6) O. Rüdiger, u. W. Kinna : Die mechanische Beanspruchung von bohrstangen beim schlagenden Gesteinsbohren, Glückauf, 49/50, 1953

7) H. Scheffler : Dil Mechanik des rückstosses von Druckluft-schlag*werkzengen, Glückauf, 15/16, 1954

\section{めずらしい坑気調整法}

めずらしい坑気調整法がカナダのオンタリオにあ る International Nickel Co.の Frood-stobie 銑 山で用いられている。

この方法は寒い冬に坑内で水在作ら也て，ての潜 埶で坑気死あたため，夏はその水で坑内党泠却方る そいう万法である。

図に示すように扇風機で深さ $300 \mathrm{ft}$ 直径 $20 \mathrm{ft}$ 立坑に風在吹き下し $300 \mathrm{ft}$ と $500 \mathrm{ft} レ$ レ゙の間にある 大きな切羽汇送り込んでやる。この切羽の天井には 4 点から水が出るようにパイプラインがしかれてい る。水量踤るが最大 200 ガロン/ minまでである。 冬汏気がつめたいのでこの水が氷に変り,この過 程において潜熱を出し坑気老あたためる。去年の冬 には40,000 t の水が勿羽つ下底に出来た。岩壁から 笁気に吸収きれた熱量な15 億Btuにも達し，これ は100,000 ガロンの油を燃焼させたと同しである。

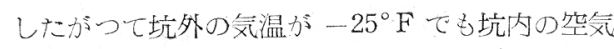

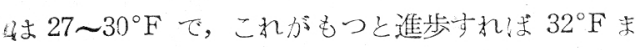
ではあけられる。

この装置で流される空気量は最大 750,000 efmで 140,000 t の水が冬の間:作られる。夏の間は空気が この水によつて冷却され 5〜 $10^{\circ}$ 気温が下る。(田中)

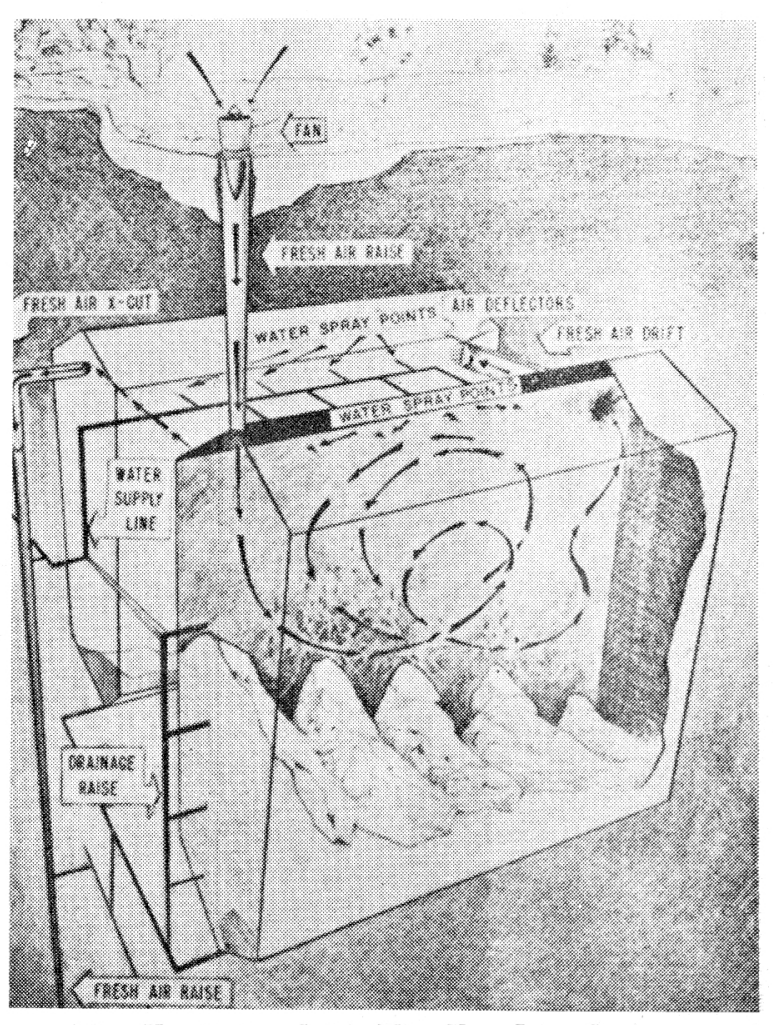

Mine Ventilation, Stobie Mine Uses Icing System to Worm and Cool Air; Mining Eng'g. July 1956 p. 685 より 